\title{
ADOLESCENT IDIOPATHIC SCOLIOSIS AND SIMILAR CONDITIONS: NEW TOOL TO MEASURE THE CORONAL PLANE
}

\author{
ESCOLIOSE IDIOPÁTICA DO ADOLESCENTE E SIMILARES: NOVA FERRAMENTA PARA \\ MEDIR O PLANO CORONAL
}

\author{
ESCOLIOSIS IDIOPÁTICA DEL ADOLESCENTE Y AFECCIONES SIMILARES: NUEVA \\ HERRAMIENTA PARA MEDIR EL PLAN CORONAL
}

Enguer Beraldo Garcia, ${ }^{1,2,3}$ Guilherme Brescia Payão, ${ }^{2}$ Lillane Faria Garcia, ${ }^{1,2}$ Enguer Beraldo Garcia Jr, ${ }^{2}$ Marcos Felipe Camarinha, ${ }^{2}$ Roberto Garcia Gonçalves, ${ }^{1,3}$ Juliana Garcia Camarinha, ${ }^{2}$ Saulo Terror Giesbrech, ${ }^{1,3}$ Victor de Oliveira Matos $^{1}$

1. Spine Group, da Santa Casa de Belo Horizonte, MG, Brazil.

2. Instituto da Coluna Vertebral de Belo Horizonte, Belo Horizonte, MG, Brazil.

3. Sociedade Brasileira de Coluna, São Paulo, SP, Brazil.

\begin{abstract}
Objective: To create a method to measure the overall coronal plane of the spine, called the sacral clavicular angle (SCA). Methods: A line is drawn at the base of the sacrum; a second central line is drawn perpendicular to the first one in the proximal extension of the spine. A third line is drawn passing through the intersections of the superior points of the clavicles with the two second ribs, forming two angles, the greater of which is measured. Therefore, the degrees exceeding $90^{\circ}$ are the SCA values. This tool was tested retrospectively in a study of 46 patients with idiopathic scoliosis who underwent short, apical, single or multiple fixations. Third generation instrumentation was used and the SCA was evaluated in the preand postoperative periods, which were compared with another group of 46 patients treated with the traditional technique. Results: Patients submitted to the traditional fixation method presented a median SCA of $3^{\circ}$ in the preoperative period, and in the postoperative period, the SCA remained in $3^{\circ}$. Therefore, there was a $0 \%$ reduction. Patients submitted to short, apical, single or multiple fixation method presented a median preoperative SCA of $6^{\circ}$, and a postoperative median SCA of $1^{\circ}$, a reduction of approximately $83 \%$. Conclusions: The group treated with short, apical, single or multiple instrumentation presented a reduction in the SCA of approximately $83 \%$ in the postoperative period compared to the preoperative period. The difference between preoperative and postoperative values was considered statistically significant. Level of Evidence II; Retrospective study.
\end{abstract}

Keywords: Scoliosis; Preoperative care; Postoperative care.

\section{RESUMO}

Objetivo: Criar um método para mensurar o plano coronal global da coluna vertebral, denominado Ângulo Sacro Clavicular (ASC). Métodos: Executa-se uma linha na base do sacro, faz-se uma segunda linha central perpendicular a primeira na extensão proximal da coluna. Executa-se uma terceira linha passando nos pontos de encontro superiores das clavículas com as duas segundas costelas formando dois ângulos, mensura-se o maior. Portanto, os graus excedentes a $90^{\circ}$ são os valores do ASC. Testou-se essa ferramenta estudando, retrospectivamente, 46 pacientes portadores de escoliose idiopática, que se submeteram às fixações curtas, apicais, únicas ou múltiplas. Usou-se instrumental terceira geração, avaliando o ASC no pré e pós-operatório, os quais foram comparados com outro grupo de 46 pacientes, abordados com a técnica tradicional. Resultados: Os pacientes pertencentes ao método de fixação tradicional apresentaram uma mediana de 3,0 referente ao ASC no pré-operatório. No pós-operatório, a mediana manteve-se em $3^{\circ}$, portanto houve uma redução de $0 \%$. Os pacientes pertencentes ao método de fixação curta, apical, única ou múltipla apresentaram no pré-operatório a mediana de $6^{\circ}$, no pós-operatório de $1^{\circ}$, redução de aproximadamente $83 \%$ no pós-operatório. Conclusões: O grupo abordado com instrumentação curta, apical, única ou múltipla, apresentou uma redução de aproximadamente 83\% no pós-operatório em relação ao pré-operatório. A diferença entre o pré e o pós-operatório foi considerada estatisticamente significativa. Nível de Evidência II; Retrospectivo.

Descritores: Escoliose; Cuidados pré-operatórios; Cuidados pós-operatórios

\section{RESUMEN}

Objetivo: Crear un método para mensurar el plano coronal general de la columna vertebral, llamado ángulo sacro clavicular (ASC). Métodos: Se hizo una línea en la base del sacro; una segunda línea central se hizo perpendicular a la primera en la extensión proximal de la columna vertebral. Se hizo una tercera línea que pasa a través de las intersecciones de las porciones superiores de las clavículas con las dos segundas costillas, formando dos ángulos, el mayor de los cuales se midió. Por lo tanto, los grados superiores a $90^{\circ}$ son los valores del ASC. Esta herramienta fue probada retrospectivamente en un estudio de 46 pacientes con escoliosis idiopática que se sometieron a fijaciones cortas, apicales, únicas o múltiples. Se utilizó instrumentación de tercera generación y se evaluó el ASC en los períodos pre y postoperatorio, que se compararon con otro grupo de 46 pacientes tratados con la técnica tradicional. Resultados: Los pacientes sometidos al método de fijación tradicional presentaron una mediana de ASC de $3^{\circ}$ en el período preoperatorio, y en el postoperatorio, el ASC se mantuvo en $3^{\circ}$. Por lo tanto, hubo una reducción del $0 \%$. Los pacientes sometidos a un método de fijación corta, apical, única o múltiple presentaron una mediana de ASC preoperatoria de $6^{\circ}$ y una mediana de ASC postoperatoria de $1^{\circ}$, una reducción de aproximadamente 83\%. Conclusiones: El grupo tratado con instrumentación corta, apical, única o múltiple presentó una reducción en el ASC de aproximadamente $83 \%$ en el período postoperatorio en comparación con el período preoperatorio. La diferencia entre los valores preoperatorios y postoperatorios se consideró estadísticamente significativa. Nivel de Evidencia Il; Estudio retrospectivo.

Descriptores: Escoliosis; Cuidados preoperatorios; Cuidados posoperatorios. 


\section{INTRODUCTION}

Scoliosis is a deformity with a lateral deviation in the coronal plane of the spine that can be observed in infants, children, adolescents, and adults, depending on the type of scoliosis in question. Idiopathic scoliosis is characterized as a three-dimensional deformity of the spine, but, in addition to the lateral curve, it involves spinal rotation and is more prevalent in female adolescents. ${ }^{1}$

Radiographic studies are fundamental to the evaluation of scoliosis and the posterior anterior view is the standard for measuring these curves. Today, the Cobb ${ }^{2}$ and Ferguson ${ }^{3}$ methods are the most commonly used to monitor and observe the patient's condition and assess the progression of the deformity by quantifying the curve. The Cobb method, in particular, is recommended by the Scoliosis Research Society and widely used in clinical practice and is the gold standard for treatment planning and results evaluation. ${ }^{6}$

The Cobb technique measures the amplitude of the curve by measuring and calculating the angle between the lines drawn tangent to the superior terminal plate of the cranial vertebra and the inferior terminal plate of the caudal vertebra, respectively, of the scoliotic curve to be measured. ${ }^{6,7}$ Several studies have reported that the Cobb method is prone to error and is not reliable. .,8-10 $^{-10}$

Garcia et al. created a new principle of instrumentation for the surgical treatment of adolescent idiopathic scoliosis (AIS) and similar conditions, using short, apical, single or multiple fixations, which produce excellent spinal correction, especially for more distal curves. ${ }^{11}$

The objective of this study was to create a method to measure the overall coronal plane of the scoliotic spine, called the sacral clavicular angle (SCA), to monitor the real balance of this plane during surgical treatment of scoliosis.

\section{METHODS}

The project was submitted by the Santa Casa de Belo Horizonte on 05/17/17 and approved as CAAE number 68440417.2.0000.5138. The study participants signed the Informed Consent Form.

The Spine Groups of the Instituto da Coluna Vertebral and of the Orthopedics and Traumatology Service of the Santa Casa, both located in Belo Horizonte, created a new tool to measure the overall coronal plane of the spine called the Sacral Clavicular Angle (SCA).

To measure the SCA, a line is drawn parallel to the base of the sacrum ${ }^{12}$ and a second line is drawn from the center of and perpendicular to the first one for the entire extension of the spine. A third line is drawn passing through the intersections of the superior portions of the clavicles with the second ribs, thus forming two angles, which measure $90^{\circ}$ by $90^{\circ}$ in non-scoliotic people. The standard established was to measure the greater angle on the side exceeding $90^{\circ}$ with the goniometer and the SCA value was defined as the number of degrees in excess of $90^{\circ}$. (Figure 1)

To test the new tool, we studied the pre- and postoperative SCAs of 46 patients submitted to short, apical, single or multiple fixation surgeries using 3rd generation instumentation. Eleven were excluded because the images were not suitable for the study. These were compared with 46 other patients, who had also undergone surgery with 3rd generation instrumentation, using the traditional technique. The participants were randomly selected from a total of 450 patients operated in the service.

The authors used the patients' medical record data and images. The SCA was measured from pre- and postoperative panoramic posterior anterior $\mathrm{X}$-rays of the patients in the standing position. All the study variable data was gathered and loaded into spreadsheets for the biostatistical study.

First, an exploratory analysis was conducted using frequency distributions for the demographic and clinical data in order to characterize the patient sample.

A contingency table was used to associate patient sex and race with the type of method applied, traditional fixation of short, apical, single or multiple fixation. The Fisher's chi-square test was adopted to test the statistical significance of the association between these variables.

The parametric t test for independent samples was used to test the difference between the ages of the patients by method applied, traditional fixation or short, apical, single or multiple fixation.

To evaluate the differences between the preoperative and postoperative findings for the patients being studied, the non-parametric Wilcoxon test was used for each method, since the data did not follow Gauss distribution.

The parametric t test for independent variables was used to compare the pre- and postoperative SCA values between traditional fixation and short, apical, single or multiple fixation methods.

The study data were analyzed using the PASW statistical program, version 18. In all the statistical tests performed, a significance level of $5 \%$ was considered. Thus, associations with a p-value less than 0.05 were considered to be statistically significant. ${ }^{13}$

\section{RESULTS}

In a comparative analysis between the groups defined by fixation method applied, either traditional or short, apical, single or multiple, by sex, race, and age range, as observed in Table 1 and Table 2, there was no difference between the groups in terms of demographic characteristics, since the $p$-value was $>0.05$.

In Table 3 and Figure 2, we observe that the patients in the traditional fixation group had both a mean preoperative SCA of $3^{\circ}$ and

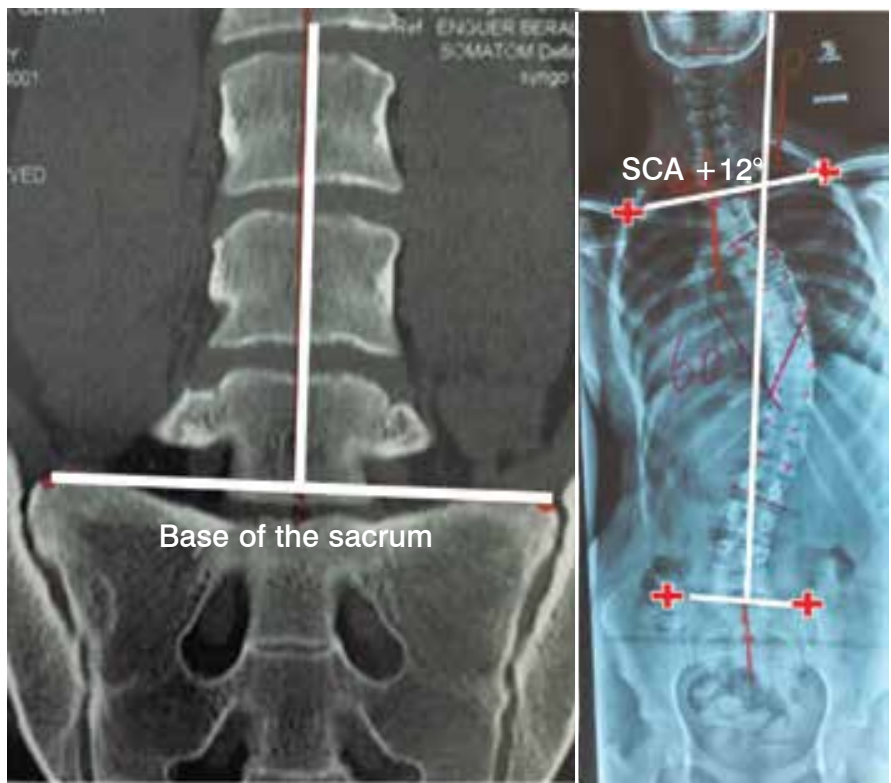

Figure 1. Measurement of the Sacral Clavicular Angle (SCA)

Table 1. Frequency distribution of traditional and short, apical, single or multiple fixation patients by demographic characteristics.

\begin{tabular}{|c|c|c|c|c|c|c|}
\hline \multirow[t]{3}{*}{ Demographics } & \multicolumn{5}{|c|}{ Method } & \multirow{3}{*}{ P-value } \\
\hline & \multicolumn{2}{|c|}{ Multiple fixation } & \multicolumn{2}{|c|}{ Traditional fixation } & & \\
\hline & $\mathbf{n}$ & $\%$ & $\mathbf{n}$ & $\%$ & & \\
\hline \multirow{2}{*}{ sex } & Female & 44 & $95.7 \%$ & 40 & $87.0 \%$ & 267 \\
\hline & Male & 2 & $4.3 \%$ & 6 & $13.0 \%$ & \\
\hline \multirow{3}{*}{ race } & White & 41 & $89.1 \%$ & 42 & $93.5 \%$ & .359 \\
\hline & Mixed & 3 & $6.5 \%$ & 3 & $6.5 \%$ & \\
\hline & Black & 2 & $4.3 \%$ & 1 & $0 \%$ & \\
\hline Total & & 46 & $100 \%$ & 46 & $100 \%$ & \\
\hline
\end{tabular}

The probabilities of significance ( $p$-value) refer to the chi-square test.

Table 2. Frequency distribution of traditional and short, apical, single or multiple fixation patients by demographic characteristics.

\begin{tabular}{c|c|c|c|c|c|c}
\hline Variable & Method & $\mathbf{N}$ & Mean & S.D. & t Statistic & P-value \\
\hline \multirow{2}{*}{ age } & $\begin{array}{c}\text { Traditional } \\
\text { fixation }\end{array}$ & 46 & 15.59 & 4.68 & & \multirow{2}{*}{-.708} \\
\hline & $\begin{array}{c}\text { Multiple } \\
\text { fixation }\end{array}$ & 46 & 1637 & 5.85 & .480 \\
\hline
\end{tabular}

The probabilities of significance ( $p$-value) relate to the $t$ test for independent samples. 
Table 3. Frequency distribution of the 46 patients in each method by SCA measured.

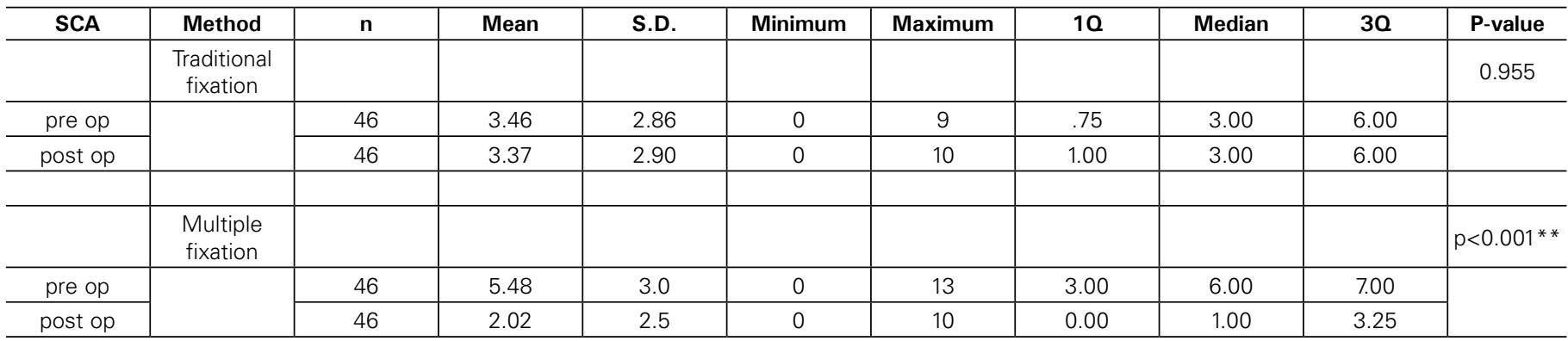

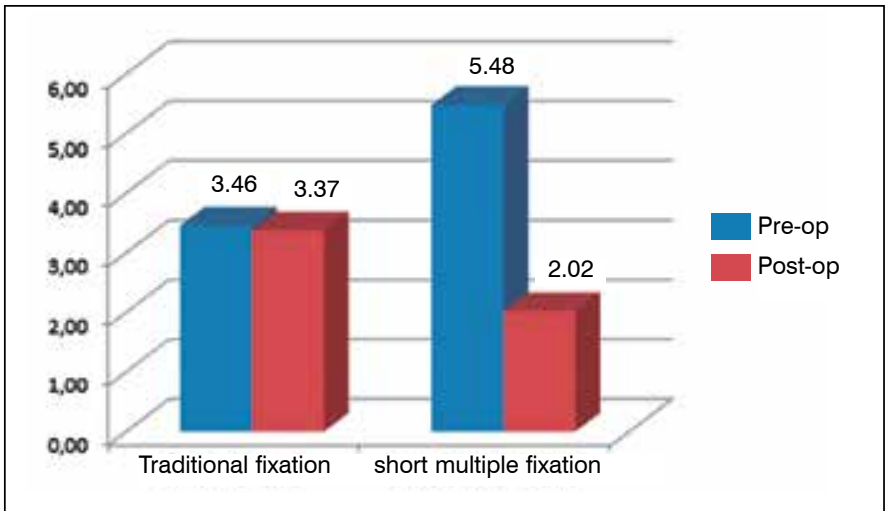

Figure 2. Frequency distribution of the 46 patients in each method by SCA measured.

a mean postoperative SCA of $3^{\circ}$. Comparing these two moments, there was a reduction of $0 \%$ in the postoperative period in relation to the preoperative period. The statistical test confirmed that the difference between the preoperative and postoperative values was considered to be non-significant.

Also, in Table 3 and Figure 2, a preoperative median of $6^{\circ}$ is observed in the patients belonging to the short, apical, single or multiple fixation method, while in the postoperative period the median was $1^{\circ}$. Comparing these two moments, there was a reduction of approximately $83 \%$ in the postoperative value in relation to the preoperative value. The statistical test confirmed that the difference between the pre- and postoperative values is significant.

According to the results in Table 4 and Figure 3, the $t$ test confirmed that a statistical difference exists between the reductions in the angles of the traditional and short, apical, single or multiple methods. The short, apical, single or multiple fixation method reduced the angle more than the traditional method. That is, the postoperative reduction averaged $3.46^{\circ}$ for the short, apical, single or multiple fixation and $0.09^{\circ}$ for the traditional method.

Table 5 shows that among the 46 patients in the traditional method group 8 or $17.4 \%$ had a postoperative increase in the angle, while among the 46 patients in the short, apical, single or multiple fixation method group 4 or $8.7 \%$ had a postoperative increase in the angle.

\section{DISCUSSION}

The purpose of short and selective fixation in the correction of AlS was achieved with 3rd generation instrumentation, but for many years we, as well as other authors, ${ }^{14-17}$ have observed the frequent presence of trunk imbalance. Therefore, the creation of this new tool to measure the SCA may be quite timely.

Considering the worldwide lack of a tool that can measure the overall coronal plane of the spine mathematically to determine whether corrective surgeries for scoliosis using 3rd generation instrumentation are really balancing or unbalancing the trunk, we created the Sacral Clavicular Angle (SCA). Figures 4 to 8.
Table 4. Assessment of the difference between the pre- and postoperative angles for the traditional and short, apical, single or multiple fixation methods.

\begin{tabular}{c|c|c|c|c|c|c}
\hline Variable & Method & $\mathbf{N}$ & Mean & S.D. & t Statistic & P-value \\
\hline \multirow{2}{*}{ difference } & $\begin{array}{c}\text { Multiple } \\
\text { fixation }\end{array}$ & 46 & 3.46 & 3.33 & \multirow{2}{*}{4.22} & \multirow{2}{*}{$.000^{* *}$} \\
\cline { 2 - 5 } & $\begin{array}{c}\text { Traditional } \\
\text { fixation }\end{array}$ & 46 & 0.09 & 4.26 & & \\
\hline
\end{tabular}

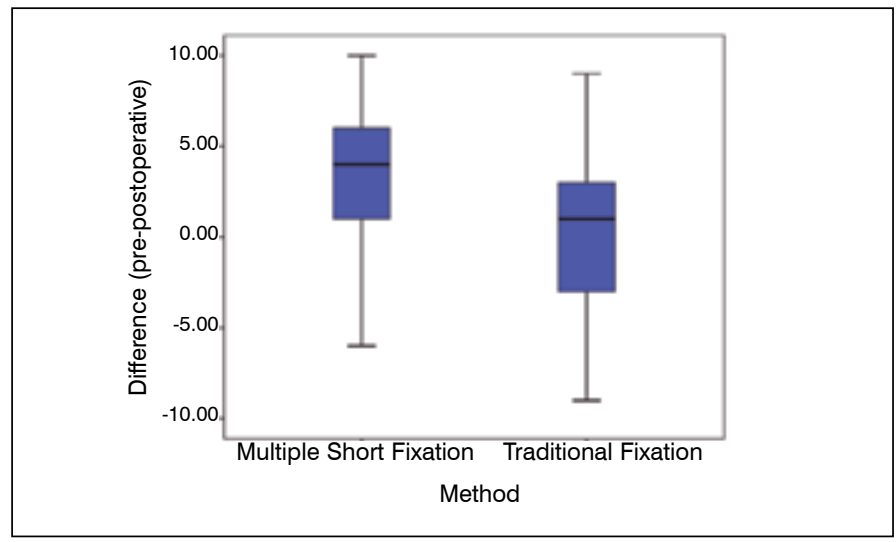

Figure 3. Assessment of the difference between pre- and postoperative angles for the short, apical, single or multiple fixation and traditional fixation methods.

Table 5. Frequency distribution of the 46 patients in each method by postoperative angle.

\begin{tabular}{c|c|c|c}
\hline \multicolumn{2}{c|}{ Method } & n & $\%$ \\
\hline $\begin{array}{c}\text { Short, apical, single or } \\
\text { multiple fixation }\end{array}$ & $\begin{array}{c}\text { Worse in the } \\
\text { postoperative }\end{array}$ & 4 & 8.7 \\
\hline & Total & 46 & 100.0 \\
\hline Traditional fixation & $\begin{array}{c}\text { Worse in the } \\
\text { postoperative }\end{array}$ & 8 & 17.4 \\
\hline & Total & 46 & 100.0 \\
\hline
\end{tabular}

A quality image is necessary to show the strategic points for the measurement of the SCA, hence our exclusion of 11 of the original study group of 57 patients submitted to multiple fixations due to unsatisfactory images. Great accuracy is recommended when tracing and measuring the angle. Mathematical quantification is indispensable to confirm whether the trunk is imbalanced.

We believe that the correction and stabilization in order to align the curves of scolioses with structural curves of evolutionary tendencies, but I am concerned that we may cause greater trunk imbalance.

The SCA may initially be positive and become negative postoperatively and vice-versa. Figures 4 to 8 . 


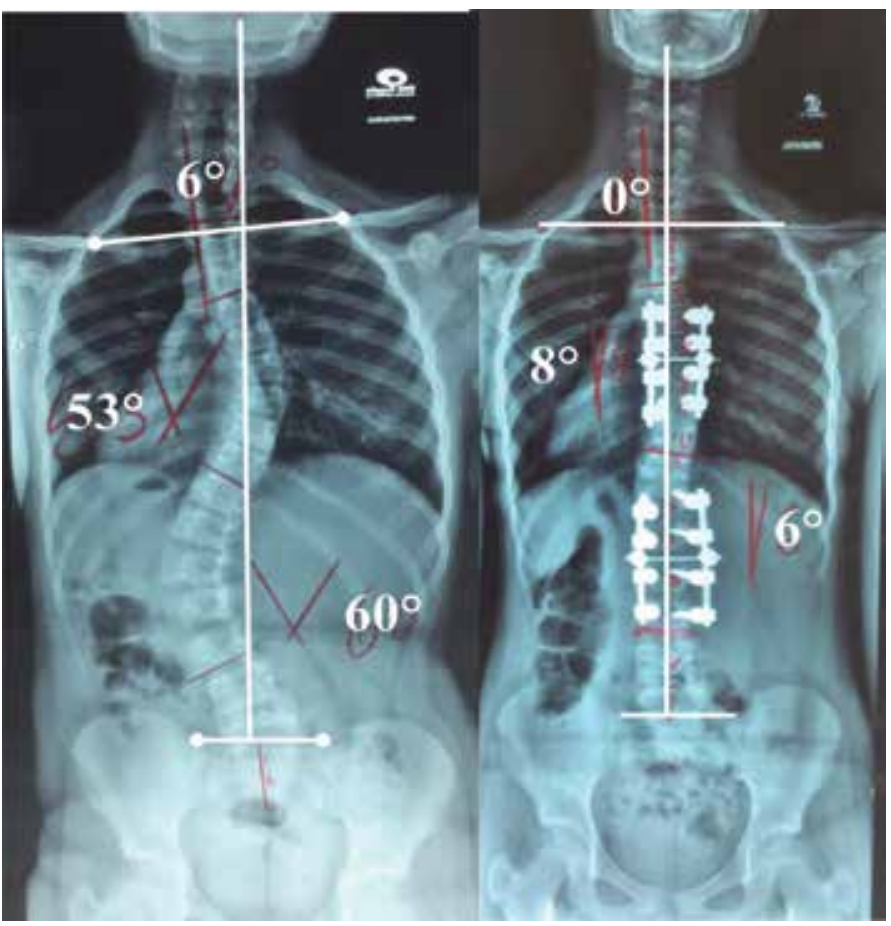

Figure 4. Patient, 11 years of age, female, with preoperative SCA of plus $6^{\circ}$ submitted to short, apical, and multiple fixations. The SCA was corrected to $0^{\circ}$ in the postoperative. Note the balance of the shoulders.

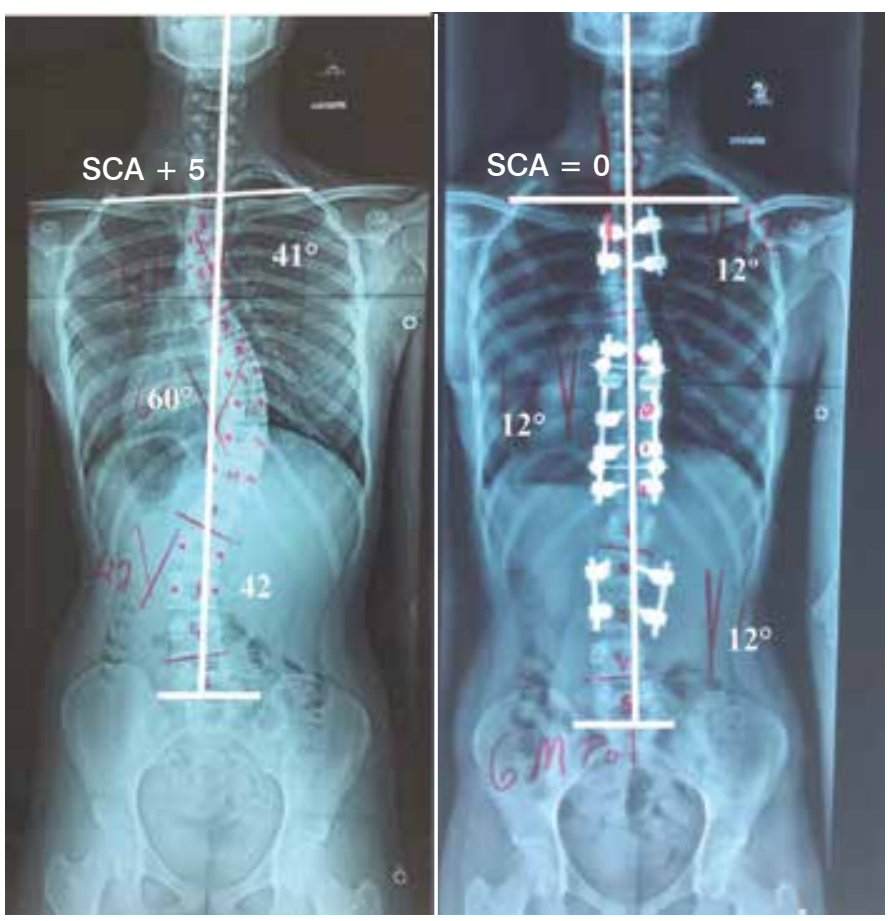

Figure 5. Patient, 14 years of age with preoperative SCA of plus $5^{\circ}$, submitted to multiple fixations, correcting the angle to $0^{\circ}$ postoperatively. Note the balance of the shoulders.

Among the 46 patients studied who were submitted to the traditional method, 8 or $17.4 \%$ had a postoperative increase in the SCA, while among the 46 patients operated by the short, apical, single or multiple fixation method, 4 or $8.7 \%$ had an increased postoperative angle. It is therefore evident that this new fixation principle may be a good option. Tables 3 to 5, Figures 1 to 6.

In this study, the median postoperative SCA of patients operated

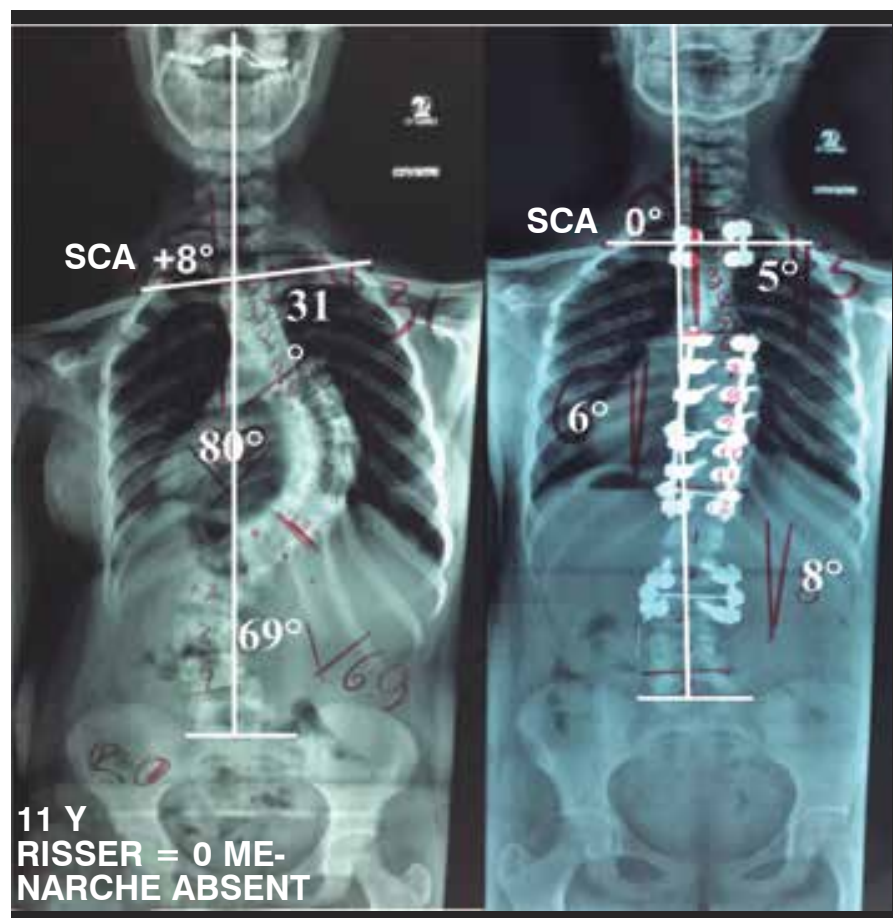

Figure 6. Patient, 11 years of age, female, presenting preoperative SCA of plus $8^{\circ}$, submitted to apical, short, and multiple fixations, showing a postoperative SCA of $0^{\circ}$. Note the balance of the shoulders.

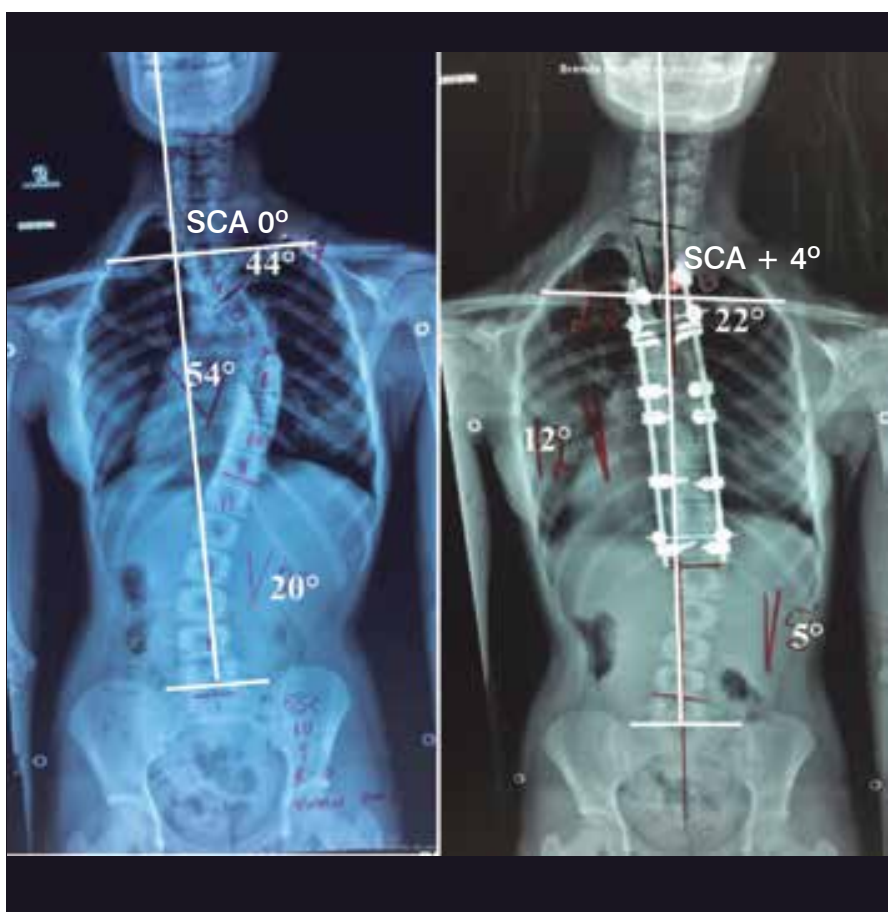

Figure 7. Patient, 12 years of age, female, with preoperative SCA of $0^{\circ}$ submitted to selective traditional fixation worsened to a postoperative SCA of plus $4^{\circ}$. Note the fallen right shoulder, the cervical spine now inclined to the right, and the imbalance of the trunk.

by the traditional method showed no correction. Figure 7 and 8.

The patients who were submitted to the short, apical, single or multiple fixation method had a reduction of approximately $83 \%$ in the postoperative as compared to the preoperative median SCA. Table 3, Figures 1, 4-6.

Because the Cobb method is considered the gold standard 


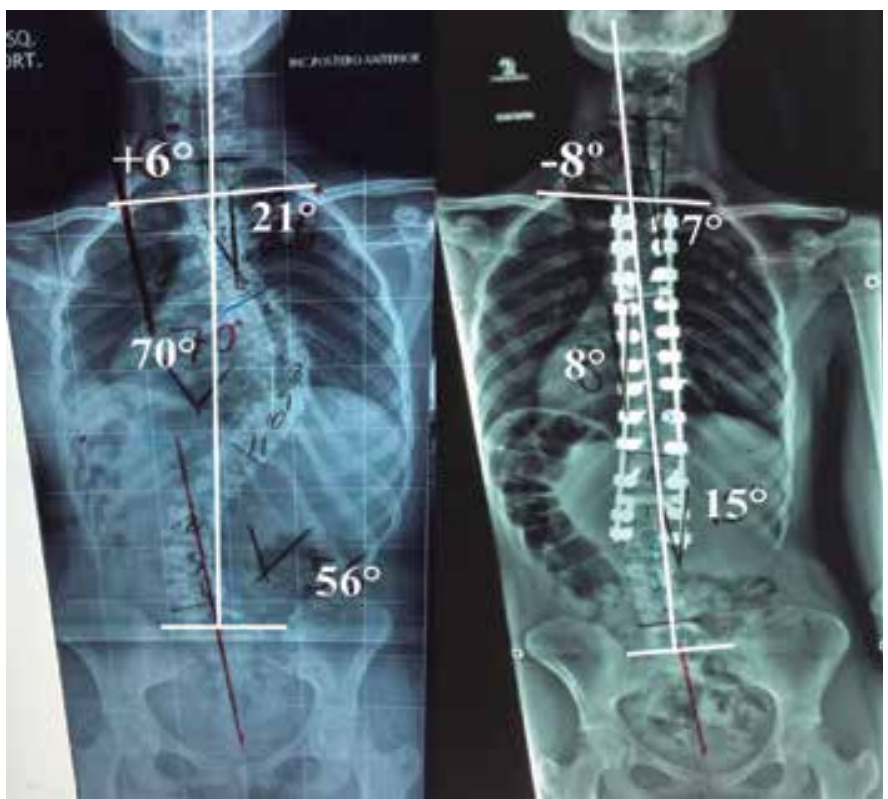

Figure 8. Patient, 12 years of age, female with preoperative SCA of $+6^{\circ}$, submitted to selective traditional fixation increasing to a postoperative SCA of $-8^{\circ}$ and showing the fallen right shoulder and marked imbalance of the trunk. for planning the treatment of deformity and evaluating the results, ${ }^{6}$ measuring the magnitude of each curve separately, a gap is left open for a tool that can measure the overall coronal plane before and after scoliosis treatment, be it clinical or surgical. It is precisely to meet this demand that the SCA emerges, making it possible for us to know if we are truly producing gold standard results in relation to the balance of the coronal plane.

\section{CONCLUSIONS}

This "new tool" to measure the SCA lets us quantify mathematically the balance of the overall coronal plane of the spine. It was evident that the group treated with short, apical, single or multiple instrumentation has a reduction of approximately $83 \%$ postoperatively as compared to the preoperative period, while the patients treated with traditional fixation had a reduction of $0 \%$. This difference between preand postoperative was confirmed as statistically significant by the biostatistical test.

All authors declare no potential conflict of interest related to this article.

CONTRIBUTION OF THE AUTHORS: Each author made significant individual contributions to this manuscript. EBG (0000-0002-1737-7811)* was the main author. GBP (0000-0001-6812-1245)*, LFG (0000-0002-2425-8802), EBGJ (0000-0002-7612-2579)*, JGC (0000-0003-4054-0821)*, and MFC $(0000-0001-9741-1727)^{\star}$ contributed greatly to the preparation of the article. RGG (0000-0003-0376-8763)*, STG (0000-0002-8482-479X)*, and VOM $(0000-0001-8808-4787)^{\star}$ reviewed the manuscript. ${ }^{\star}$ RCID (Open Researcher and Contributor ID).

\section{REFERENCES}

1. Bunnell WP. The natural history of idiopathic scoliosis. Clin Orthop Relat Res. 1988;(229):20-5

2. Cobb J. Outline for the study of scoliosis. Instr Course Lect. 1948;5:261.

3. Ferguson $A B$. The study and treatment of scoliosis. South Med J Birmingham. 1930;23(2):116-20

4. He JW, Yan ZH, Liu J, Yu ZK, Wang XY, Bai GH, et al. Accuracy and repeatability of a new method for measuring scoliosis curvature. Spine (Phila Pa 1976). 2009;34(9):E323-9.

5. Srinivasalu S, Modi HN, Smehta S, Suh SW, Chen T, Murun T. Cobb angle measurement of scoliosis using computer measurement of digitally acquired radiographs-intraobserver and interobserver variability. Asian Spine J. 2008;2(2):90-3.

6. Mehta SS, Modi HN, Srinivasalu S, Chen T, Suh SW, Yang JH, et al. Interobserver and intraobserver reliability of Cobb angle measurement: endplate versus pedicle as bony landmarks for measurement: a statistical analysis. J Pediatr Orthop. 2009;29(7):749-54.

7. Zhang J, Lou E, Le LH, Hill DL, Raso JV, Wang Y. Automatic Cobb measurement of scoliosis based on fuzzy Hough Transform with vertebral shape prior. J Digit Imaging. 2009;22(5):463-72.

8. Allen $\mathrm{S}$, Parent $\mathrm{E}$, Khorasani M, Hill DL, Lou E, Raso JV. Validity and reliability of active shape models for the estimation of cobb angle in patients with adolescent idiopathic scoliosis. J Digit Imaging. 2008;21(2):208-18.

9. Sperandio FF, Tavares GMS, Santos GM. Reprodutibilidade intra e interobservadores no ângulo de Cobb em indivíduos escolióticos. Rev Bras Cresc Desenv Hum. 2011;21(1):21-9.
10. Godinho RRS, Uetall RHS, Curtoll DD, MartinsIII DE, Wajchenberg M, Puertas EB. Mensuração da curva escoliótica pela técnica de Cobb intraobservadores e interobservadores e sua importância clínica. Coluna/Columna. 2011;10(3):216-20.

11. Garcia EB; Garcia LF; Garcia Jr EB; Camarinha MF; Camarinha JG, et al. Escoliose idiopática do adolescente: fixações curtas, apicais, únicas ou múltiplas. [PRELO]

12. Paulsen F, Waschke J. Anatomia Geral Sistema Muscular. In: Paulsen F. Sobotta, Atlas de Anatomia Humana. 3.ed. Rio de Janeiro: Guanabara Koogan, 2012. p.39-126.

13. Koch GG, Landis JR, Freeman JL, Freeman DH, Lehnen RC. A general methodology for the analysis of experiments with repeated measurement of categorical data. Biometrics. 1977;33(1):133-58.

14. Frez R, Cheng JC, Wong EM. Longitudinal changes in trunkal balance after selective fusion of King II curves in adolescent idiopathic scoliosis. Spine (Phila Pa 1976). 2000;25(11):1352-9.

15. Richards BS. Lumbar curve response in type II idiopathic scoliosis after posterior instrumentation of the thoracic curve. Spine (Phila Pa 1976). 1992;17(8 Suppl):S282-6.

16. Li M, Shen Y, Fang X, Ni J, Gu S, Zhu X, et al. Coronal and sagittal plane correction in patients with Lenke 1 adolescent idiopathic scoliosis: a comparison of consecutive versus interval pedicle screw placement. J Spinal Disord Tech. 2009;22(4):251-6.

17. Richards BS, Scaduto A, Vanderhave K, Browne R. Assessment of trunk balance in thoracic scoliosis. Spine (Phila Pa 1976). 2005;30(14):1621-6. 